Wahyu Wardiana Dewi, 2016. Respon Dosis Pupuk Kandang Kambing Terhadap

Pertumbuhan dan Hasil Tanaman Mentimun (Cucumis sativus L.)Varietas Hibrida . Journal Viabel Pertanian. (2016), 10(2) 11- 29

\title{
RESPON DOSIS PUPUK KANDANG KAMBING TERHADAP PERTUMBUHAN \\ DAN HASIL TANAMAN MENTIMUN (Cucumis sativus L.) VARIETAS HIBRIDA
}

\author{
Wahyu Wardiana Dewi \\ Program Studi Agroteknologi, Fakultas Pertanian, Universitas Islam Balitar, Blitar
}

\begin{abstract}
This research is aimet to known the responsed of cucumber plant (Cucumis sativus L.), the good means for the growth and yield of cucumber (Cucumis sativus L) of the hybrid varieties doses of good means. This study uses a randomized block design (RAK) with one factor and 5 replications. The main factors, namely: goat manure. First repeat that: without fertilizer (P0), manure goat 10 ton / ha (P1), manure goat 20 ton / ha (P2), manure goat 30 ton / ha (P3), and the latter is manure goat 40 ton / ha (P4). The parameters observed were plant height, leaf number, fruit weight, fruit length and diameter of the fruit. Data analysis by using analysis of variance (ANOVA), if the effect followed by Least Significant Difference Test (BNT). The results based on the analysis of variance showed that: 1) Treatment of manure goat (P) significantly affected the growth and yield of cucumber plants include all the parameters of observation starting plant height, leaf number, fruit weight, fruit length and fruit diameter. Dose goat manure $40 t /$ ha is the best concentration to produce the highest average values for all parameters. The lowest value of all parameters are shown on the dose P0 (without manure goat / control).
\end{abstract}

Keywords: cucumber, goat manure.

\section{PENDAHULUAN}

Tanaman mentimun (Cucumis sativus L.) bukan tanaman asli Indonesia, tetapi berasal dari daerah beriklim sedang (sub tropis). Pada mulanya tanaman mentimun tumbuh secara liar di bagian utara India, tepatnya di lereng gunung Himalaya. Mentimun liar yang ditemukan tumbuh di wilayah ini yaitu cucumic hardwichii Royle (Tindal,1987 dalam Prasodjo Soedomo,R, dan Hendro Sunaryono, 1990). Menurut Whitaker dan Bemis (1976), jenis mentimun liar yang tumbuh di lereng gunung Himalaya, India merupakan salah satu penyimpangan dari jenis mentimun, karena jumlah kromosomnya 7 pasang $(\mathrm{n}=14 \mathrm{n})$. Jenis mentimun yang umum ( normal ) mempunai umlah kromosom 2 $\mathrm{n}=2 \mathrm{x}=24$, yang sebagian besar terdapat di Afrika (Wiyanta, 2005). 
Pertama kali mentimun di budidayakan oleh manusia 1000 (seribu) tahun yang lalu. Colombus disebut - sebut sebagai orang yang berjasa menyebarluaskan tanaman mentimun ke seluruh dunia. Di Cina mentimun mulai di kenal dua abad sebelum masehi, tanaman mentimun juga menyebar di Timur Tengah, kemudian meluas ke Negara Negara lain dikawasan Asia, sedangkan penyebaran mentimun di Amerika adalah California, New York, Carolina Selatan, Texas dan Florida. Pembudidayaan mentimun meluas keseluruh dunia, baik di daerah beriklim panas (tropis) maupun daerah beriklim sedang (sub tropis).

Di Indonesia tanaman mentimun banyak di tanam di dataran rendah. Pada tahun 1991, daerah penyebaran yang menjadi pusat pertanaman mentimun adalah provinsi Jawa Barat, Daerah Istimewa Aceh, Bengkulu, Jawa Timur dan Jawa Tengah (Ashari, 1995).

Mentimun (Cucumis sativus L.) adalah salah satu sayuran buah yang banyak dikonsumsi masyarakat Indonesia dalam bentuk segar. Nilai gizi mentimun cukup baik karena sayuran buah ini merupakan sumber vitamin dan mineral. Kandungan nutrisi per $100 \mathrm{~g}$ mentimun terdiri dari 15 kalori, 0,8 protein, 0,1 pati, $3 \mathrm{~g}$ karbohidrat, $30 \mathrm{mg}$ fosfor, 0,5 $\mathrm{mg}$ besi, 0,02 thianine, ,01 riboflavin, natrium 5,00 $\mathrm{mg}$, niacin $0,10 \mathrm{mg}$, abu $0,40 \mathrm{gr}$, $14 \mathrm{mg}$ asam, 0,045 IU vitamin A, 0,3 IU vitamin B1 dan 0,2 IU vitamin B2 (Sumpena, 2001).

Mentimun termasuk salah satu jenis sayuran buah yang memiliki banyak manfaat dalam kehidupan masyarakat sehari - hari, sehingga permintaan terhadap komoditi ini sangat besar. Buah ini disukai oleh seluruh golongan masyarakat yang berpenghasilan rendah sampai berpenghasilan tinggi, sehingga buah mentimun dibutuhkan dalam jumlah relatif dan berkesinambungan. Kebutuhan buah mentimun cenderung terus meningkat sejalan dengan pertambahan penduduk, peningkatan taraf hidup, tingkat pendidikan, dan kesadaran masyarakat tentang pentingnya nilai gizi (Cahyono, 2003).

Peningkatan jumlah penduduk Indonesia maupun dunia meningkat permintaan sayuran. Di Indonesia anjuran konsumsi sayuran untuk mencapai sehat gizi adalah sebesar 65,5 kg/kapita/tahun. Pada tahun 1994 - 1994 konsumsi sayuran sehat gizi baru terpenuhi $80 \%$. Salah satu uapaya untuk meningkatkan persediaan sayuran adalah meningkatkan produksi mentimun (Rukmana, 1994).

Pada tahun 2006 luas areal panen mentimun nasional mencapai 55,792 ha dengan produksi 268,201 ton. Luas areal panen komoditi mentimun di Sumatera Utara pada tahun 2006 sebesar 3,591 ha dengan produksi rata - rata 125,06 kw/ha (BPS, 2006).

Produksi mentimun di Indonesia masih sangat rendah yaitu 3,5 ton/ha sampai 4,8 ton/ha, padahal produksi mentimun hibrida bisa mencapai 20 ton/ha budidaya mentimun dalam skala produksi yang tinggi dan intensif belum banyak yang dilakukan, pada umumnya tanaman mentimun di tanam hanya sebagai tanaman selingan (Warintek, 2006).

Pupuk organik apabila dilihat secara fisik ada dua macam yaitu pupuk organik cair dan pupuk organik padat. Pupuk organik padat lebih umum digunakan karena berkaitan dengan ketersediaan dan cara penggunaannya. Pupuk organik padat termasuk pupuk yang 
Wahyu Wardiana Dewi, 2016. Respon Dosis Pupuk Kandang Kambing Terhadap

Pertumbuhan dan Hasil Tanaman Mentimun (Cucumis sativus L.)Varietas Hibrida . Journal Viabel Pertanian. (2016), 10(2) 11- 29

kandungan unsur haranya dilepaskan secara perlahan - lahan. Pelepasan pupuk organic berbeda dengan pupuk kimia, pelepasan unsur hara organic akan semakin baik apabila dibantu dengan aktifitas mikroorganisme (Isnaini, 2006).

Kandungan tanah organik dalam tanah semakin lama semakin berkurang, bahan organik sering disebut sebagai bahan penyangga tanah. Tanah dengan kandungan bahan organik rendah akan berkurang kemampuannya mengikat pupuk kimia sehingga efisiensinya menurun akibat sebagian besar pupuk hilang melalui pencucian, fiksasi atau penguapan (Musnamar, 2003).

Pupuk kandang kambing mempunyai sifat memperbaiki aerasi tanah, menambah kemampuan tanah menahan unsur hara, meningkatkan kapasitas menahan air, meningkatkan daya sangga tanah, sumber energy bagi mikroorganisme tanah dan sebagai sumber unsur hara. Pupuk kandang kambing mengandung unsur $\mathrm{N}$ yang dapat mendorong pertumbuhan organ - organ yang berkaitan dengan fotosintesis yaitu daun. Kalium berperan sebagai aktivator berbagai enzim yang esensial dalam reaksi - reaksi fotosintesis dan respirasi serta enzim yang terlibat dalam sintesis protein dan pati. Unsur $P$ yang tinggi yang dapat menyusun aenosin triphosphate (ATP) yang secara langsung berperan dalam proses penyimpanan dan transfer energy yang terkait dalam proses metabolism tanaman serta berperan dalam peningkatan komponen hasil (Subhan et al.,2005 dan Rizwan, 2008).

\section{Tempat dan Waktu}

\section{METODE PENELITIAN}

Penelitian dilaksanakan di Desa Ngremang RT.03 RW.07, Kecamatan Rejotangan, Kabupaten Tulungagung mulai bulan Juli sampai Agustus 2016.

\section{Bahan dan Alat}

Bahan yang digunakan dalam penelitian ini antara lain benih mentimun, pupuk kandang kambing. Alat-alat yang digunakan dalam penelitian antara lain cangkul, polybag ukuran $6 \mathrm{~cm} \times 8 \mathrm{~cm}$, gembor, plastik mulsa, meteran, bambu, timbangan, dan alat - alat tulis.

\section{Metode Penelitian}

Peneletian ini dilakukan dengan menggunakan Rancangan Acak Kelompok dengan 5 ulangan dan 1 faktor :

$$
\begin{aligned}
\mathrm{P} 0= & \text { Tanpa pupuk kandang } \\
& \text { Kambing }(\text { Kontrol }) . \\
\mathrm{P} 1= & 10 \text { ton } / \text { ha pupuk kandang } \\
& \text { Kambing. } \\
\mathrm{P} 2= & 20 \text { ton } / \text { ha pupuk kandang } \\
& \text { Kambing. } \\
\mathrm{P} 3= & 30 \text { ton } / \text { ha pupuk kandang } \\
& \text { Kambing. } \\
\mathrm{P} 4= & 40 \text { ton } / \text { ha pupuk kandang } \\
& \text { Kambing }
\end{aligned}
$$


Wahyu Wardiana Dewi, 2016. Respon Dosis Pupuk Kandang Kambing Terhadap

Dari 5 ulangan dengan 1 faktor diatas diperoleh 25 kombinasi perlakuan yaitu:
P0 P1 P3 P4 P2
UL 1
$\begin{array}{llllllllll}\mathrm{P} & \mathrm{P} 3 & \mathrm{P} & \mathrm{P} 0 & \mathrm{P} 2\end{array}$
UL.2
$\begin{array}{lllllllllll}\mathrm{P} 0 & \mathrm{P} & \mathrm{P} 1 & \mathrm{P} 2 & \mathrm{P} 3\end{array}$
UL. 3
P4 P0 P3 P2 P1
UL.4
P3 P4 P2 P1 P0
UL.5

Dari perlakuan tersebut dihasilkan 25 perlakuan setiap perlakuan diulang 5 kali sehingga didapat 125 unit percobaan. Setiap unit terdiri dari 5 tanaman sehingga diperoleh jumlah seluruh tanaman yang dibutuhkan 125 tanaman dan diambil 3 tanaman pada setiap unit sebagai sampel.

\section{Pelaksanaan Penelitian}

Pelaksanaan penelitian ini meliputi:

Persiapan Media Semai

Pada proses persemaian, sebelum benih mentimun disemaikan terlebih dahulu direndam dengan larutan fungisida selama 15 menit dan kemudian dikering anginkan. Setelah itu, benih mentimun siap untuk disemaikan ke dalam polybag kecil ukuran $6 \mathrm{~cm} \mathrm{x}$ $8 \mathrm{~cm}$ yang sebelumnya telah di isi dengan tanah dan pasir sungai, dalam satu polybag di isi dengan satu benih mentimun. Kemudian semua polybag yang telah terisi benih mentimun di tempatkan pada rak yang telah dibuat sebelumnya. Perawatan pada benih mentimun terus dilakukan sampai menjadi bibit yang siap dipindahkan ke bedengan , bibit tanaman mentimun dapat dipindahkan pada bedengan jika telah memiliki $2-3$ helai daun atau berumur $10-14$ hari.

\section{Pengaplikasian pupuk} kandang kambing

Pengaplikasian pupuk kandang kambing yang telah di giling dilakukan pada saat 1 minggu sebelum tanam. Pupuk kandang kambing di timbang menurut perlakuan. Setiap perlakuan terdapat 5 plastik pupuk kandang kambing dengan jumlah yang sama sehingga jumlah semua plastik untuk setiap perlakuan berjumlah 25 plastik yang berisi pupuk kandang kambing. Plot yang berlabel sama akan ditabur dengan pupuk kandang sesuai perlakuan, setelah itu diratakan dengan cangkul dengan sedikit digemburkan supaya tercampur rata.

\section{Pemasangan Mulsa Plastik}

Pemasangan mulsa plastik pada saat terik matahari antara pukul $14.00-16.00$ agar plastik mulsa tersebut memanjang atau memuai dan menutupi tanah serapat mungkin. Pertama dengan menarik masing-masing ujung plastik mulsa ke ujung bedengan arah memanjang kemdian dikuatkan dengan pasak bilah bambu berbentuk "U" yang ditancapkan di setiap sisi bedengan, berikutnya tarik pula lembar mulsa plastik ke bagian sisi kanan (lebar) bedengan hingga nampak rata menutup permukaan bedengan dan kuatkan dengan pasak bilah bambu pada setiap jarak $40-50 \mathrm{~cm}$. Setelah semua mulsa plastik terpasang dilakukan pelubangan pada permukaan bedengan dengan alat pelubang sesuai pola tanam yang telah di tentukan.

\section{Penanaman}

Bibit tanaman mentimun dipindahkan secara hati - hati pada bedengan ukuran 300 $\mathrm{cm} \times 70 \mathrm{~cm}$ yang sebelumnya telah dicampur dengan pupuk kandang kambing sesuai perlakuan dan juga telah diberi label pada masing - masing bedengan sesuai perlakuan. 
Bibit tanaman mentimun yang akan dipindahkan sebelumnya telah diseleksi guna penyeragaman di dalam penanaman.

\section{Penyulaman}

Penyulaman perlu dilakukan dengan melihat keadaan tanaman dengan cara mengganti tanaman yang mati atau kurang sehat dengan tanaman baru yang memiliki keseragaman umur dan ukuran. Penyulaman dilakukan tiga hari setelah tanam.

\section{Penyiangan}

Penyiangan akan dilakukan apabila sekitar lahan di bedengan terdapat gulma. Penyiangan dilakukan satu kali dalam satu minggu dimulai dari setelah pemindahan tanaman mentimun hingga pemanenan. Penyiangan dilakukan secara mekanik di sekitar bedengan.

\section{Pemupukan}

Aplikasi pupuk NPK diberikan 2 kali yaitu pada umur 7 hst dengan dosis 2,7 gram/tanaman kemudian pada umur 14 hst dengan dosis 2,7 gram/tanaman, selanjutnya aplikasi pupuk kandang kambing diberikan pada saat pengolahan tanah sebelum penanaman dilakukan, dosis yang diberikan sesuai dengan perlakuan.

\section{Pemeliharaan Tanaman}

Pemeliharaan tanaman yang dilakukan berupa, penyiraman, pengendalian gulma, pengendalian hama dan penyakit. Tindakan pemeliharaan yang dilakukan disesuaikan dengan kondisi lapang. Penyiraman dilakukan sebanyak dua kali dalam sehari, yaitu saat pagi dan sore hari.

Pengendalian gulma dilakukan secara manual yaitu mencabut dan membuang gulma yang tumbuh di sekitar pertanaman dengan menggunakan tangan. Sementara untuk pengendalian hama dan penyakit dilakukan dengan penyemprotan pestisida. Pemeliharaan tanaman bertujuan untuk menunjang tingkat pertumbuhan tanaman di lapang dan guna menghindari adanya kontaminasi dari organisme yang dapat mengganggu pertumbuhan tanaman.

\section{Panen}

Panen dilakukan setelah tanaman berumur +/- 32 hari setelah tanam, pemanenan dilakukan secara bertahap 3 kali dalam 1 minggu. Memilih buah yang sudah layak panen yaitu buah berwarna sama mulai dari pangkal sampai ujung buah berwarna hijau keputihan. Panen dilakukan dengan cara memetik (memotong) tangkai buah dengan pisau tajam agar tidak merusak tanaman dan setelah itu buah mentimun ditimbang.

\section{Variabel Pengamatan}

Pengamatan dilakukan sejak tanaman berusia 7 hst, 14 hst, 21 hst, 28 hst serta panen dengan interval 7 hari sekali. Komponen yang diamati dalam penelitian yaitu dibedakan atas komponen pertubuhan dan komponen hasil.

Komponen pertumbuhan meliputi :

\section{Tinggi Tanaman $(\mathbf{c m})$}

Pengamatan tinggi tanaman dilakukan dari pangkal batang sampai ujung daun terpanjang, pengamatan dilakukan satu minggu sekali yaitu umur 7 hst, 14 hst, 21 hst, 28 hst.

\section{Jumlah Daun (helai)}

Pengamatan jumlah daun dilakukan dengan cara menghitung daun yang sudah terbuka sempurna dengan interval satu minggu sekali. 
Komponen hasil meliputi :

\section{Panjang Buah (cm)}

Pengukuran panjang buah mentimun dimulai dari pangkal buah sampai ujung buah mentimun. Pengukuran panjang buah mentimun menggunakan penggaris pada setiap tanaman sampel yang dilakukan setelah pemanenan.

\section{Diameter Buah (cm)}

Diameter buah diukur pada bagian tengan buah dengan menggunakan penggaris pada saat panen.

\section{Berat Buah (gram)}

Berat buah dihitung dengan menimbang buah yang dihasilkan dari tanaman sampel saat panen.

\section{Analisis Data}

Data hasil pengamatan pada parameter tanaman dianalisis menggunakan analisis ragam uji $\mathrm{F}$ dengan taraf nyata $5 \%$, apabila terjadi pengaruh nyata diantara perlakuan dilanjutkan dengan uji Duncan atau uji DMRT (Duncan Multiple Range Test) taraf 5\%.

\section{HASIL}

\section{HASIL DAN PEMBAHASAN}

\section{Tinggi Tanaman}

Berdasarkan hasil analisis Anova taraf 5\% menunjukkan bahwa pemberian Pupuk Kandang Kambing berpengaruh nyata terhadap tinggi tanaman mentimun pada semua umur pengamatan. (Lampiran 1). Namun pada masing-masing perlakuan Pupuk Kandang Kambing berbeda nyata pada tinggi tanaman mentimun seperti pada tabel dibawah ini :

Tabel 2. Rata-Rata Pemberian Dosis Pupuk Kandang Kambing Terhadap Tanaman Mentimun Pada Semua Umur Pengamatan.

\begin{tabular}{|c|c|c|c|c|}
\hline \multirow{2}{*}{ Perlakuan } & \multicolumn{4}{|c|}{ Tinggi Tanaman $(\mathrm{cm})$ Berbagai Umur Pengamatan (hari) } \\
\hline & 7 & 14 & 21 & 28 \\
\hline \multicolumn{5}{|c|}{ Pemberian Pupuk Kandang Kambing } \\
\hline P0 (Tanpa & & & & \\
\hline Pupuk) & $15.06 \mathrm{a}$ & $76.99 \mathrm{a}$ & $80.93 \mathrm{a}$ & $138.79 \mathrm{a}$ \\
\hline P1 (10 ton/ha) & $17.26 \mathrm{a}$ & $81.33 \mathrm{~b}$ & $88.99 \mathrm{~b}$ & $138.93 b$ \\
\hline P2 (20 ton/ha) & $18.46 \mathrm{bc}$ & $84.26 \mathrm{c}$ & $90.46 \mathrm{bc}$ & $140.79 \mathrm{a}$ \\
\hline P3 (30 ton/ha) & $19.86 \mathrm{c}$ & $85.99 \mathrm{c}$ & $93.52 \mathrm{c}$ & $144.13 b$ \\
\hline P4 (40 ton/ha) & $21.99 d$ & $88.99 d$ & $98.59 \mathrm{~d}$ & $160.13 \mathrm{c}$ \\
\hline BNT $5 \%$ & 2.38 & 2.85 & 5.06 & 2.77 \\
\hline
\end{tabular}

Keterangan: Angka-angka yang diikuti dengan huruf yang sama pada baris dan kolom yang tidak berbeda nyata pada uji DMRT taraf $5 \%$.

Pada tabel 2 ditunjukkan bahwa pemberian pupuk kandang kambing berpengaruh nyata pada tinggi tanaman umur pengamatan 7 HST. (Lampiran 1). Dengan rataan tinggi tanaman tertinggi ditunjukkan oleh P4 (Pukan Kambing 40 ton/ha) yaitu 21.99 yang berbeda nyata dengan semua umur pengamatan lain. Hasil rataan terendah ditunjukkan oleh P0 (Kontrol) yaitu 15.06 . Jika dipupuk 30 ton/ha akan meningkatkan tinggi tanaman 
Wahyu Wardiana Dewi, 2016. Respon Dosis Pupuk Kandang Kambing Terhadap Pertumbuhan dan Hasil Tanaman Mentimun (Cucumis sativus L.)Varietas Hibrida . Journal Viabel Pertanian. (2016), 10(2) 11- 29

P3 yaitu 19.86 dari tinggi tanaman P0 (Kontrol) yaitu 15.06 dan jika konsentrasi ditingkatkan 40 ton/ha sebesar 21.99 yang mampu meningkatkan hasil $0.21 \%$ pada umur 7 HST.

Selanjutnya pada umur pengamatan 14 HST pemberian Pupuk Kandang Kambing berpengaruh nyata pada tinggi tanaman. Rataan tertinggi ditunjukkan oleh perlakuan P4 (Pukan Kambing 40 ton/ha) yaitu 88.99 yang berbeda nyata dengan semua umur perlakuan lain. Hasil rataan terendah ditunjukkan oleh P0 (Kontrol) yaitu 76.99 jika dipupuk 10 ton/ha mampu meningkatkan tinggi tanaman P1 yaitu 81.33 berbeda nyata dengan P2 (20 ton/ha) dan P3 (30 ton/ha) jika dosis ditingkatkan 40 ton/ha sebesar 88.99 yang mampu meningkatkan hasil $0.88 \%$ pada umur 14 HST.

Pada umur pengamatan 21 HST hasil rataan tertinggi ditunjukkan oleh P4 (Pukan Kambing 40 ton/ha) yaitu 98.59 yang mampu meningkatkan hasil $0.98 \%$ yang berbeda nyata dengan dengan semua umur perlakuan lainnya. Hasil rataan terendah ditunjukkan oleh perlakuan P0 (Kontrol) yaitu 80.93 Jika dipupuk 30 ton/ha mampu meningkatkan tinggi tanaman 93.52 dari P0 (Kontrol) yaitu 80.93 berbeda nyata dengan P1 (Pukan Kambing 10 ton/ha) dan P2 (20 ton/ha).

Selanjutnya pada umur pengamatan 28 HST pemberian Pupuk Kandang Kambing berpengaruh nyata pada tinggi tanaman. Rataan tertinggi ditunjukkan oleh perlakuan P4 (Pukan Kambing 40 ton/ha) yaitu 160.13 yang mampu meningkatkan hasil $1.60 \%$ berbeda nyata dengan perlakuan lain. Hasil raataan terendah ditunjukkan oleh perlakuan P0 (Kontrol) yaitu 138.79 berbeda nyata dengan P1 (Pukan Kambing 10 ton/ha), P2 (Pukan Kmbing 20 ton/ha) dan P3 (Pukan Kambing 30 ton/ha) jika dosis ditingkatkan 40 ton/ha mampu meningkatkan tinggi 160.13 pada umur 28 HST.

Grafik pemberian pupuk kandang kambing pada tinggi tanaman 7 HST, 14 HST, 21 HST, 28 HST dapat dilihat pada gambar di bawah ini :

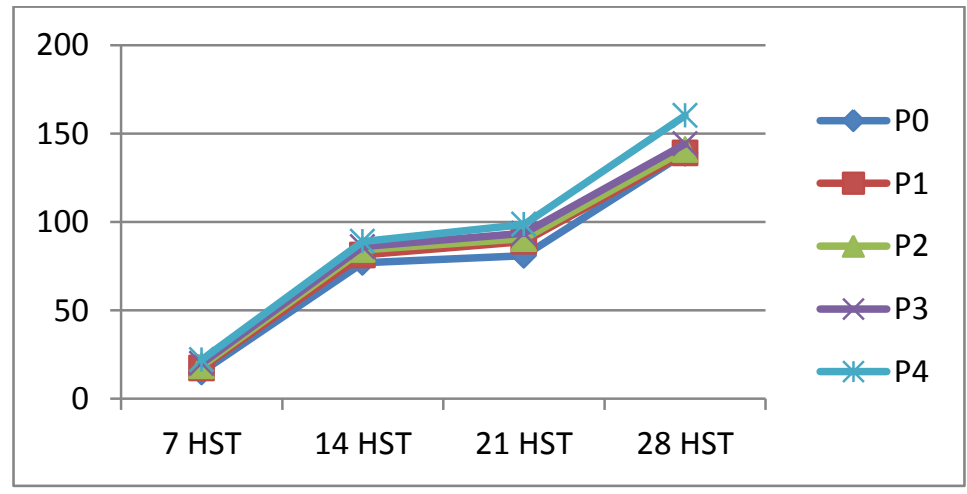

Gambar 5. Tinggi Tanaman Mentimun Terhadap Pemberian Pupuk Kandang Kambing Pada Semua Umur Pengamatan.

Hasil pengamatan pertumbuhan vegetatif yaitu tinggi tanaman dan jumlah daun (Tabel 2 dan 4) menunjukkan bahwa perlakuan pupuk kandang kambing dosis 40 ton/ha (P4) tidak berbeda dengan perlakuan pupuk kandang kambing dosis 30 ton/ha (P3). Hal 
Wahyu Wardiana Dewi, 2016. Respon Dosis Pupuk Kandang Kambing Terhadap Pertumbuhan dan Hasil Tanaman Mentimun (Cucumis sativus L.)Varietas Hibrida . Journal Viabel Pertanian. (2016), 10(2) 11- 29

ini diikuti dengan hasil pengamatan pertumbuhan generatif yaitu berat buah dan panjang buah per hektar yang lebih tinggi dan berbeda dibandingkan dengan perlakuan P0 (Tanpa Pupuk), pukan kambing dosis 10 ton/ha (P1) dan pukan kambing 20 ton/ha (P2).

\section{Jumlah Daun}

Berdasarkan hasil analisis Anova taraf 5\% menunjukkan bahwa pemberian pupuk Kandang Kambing tidak terdapat interaksi yang nyata terhadap jumlah daun tanaman mentimun pada semua umur pengamatan. (Lampiran 2).

Namun pada masing-masing perlakuan yaitu perlakuan pemberian pupuk Kandang Kambing berbeda nyata pada tinggi tanaman seperti pada tabel dibawah ini :

Tabel 4. Rata-rata Pemberian Pupuk Kandang Kambing Terhadap Jumlah Daun Tanaman Mentimun Pada Semua Umur Pengamatan.

\begin{tabular}{lllll}
\hline \multirow{2}{*}{ Perlakuan } & \multicolumn{5}{c}{ Jumlah Daun (helai) Berbagai Umur Pengamatan (hari) } \\
\cline { 2 - 5 } & \multicolumn{5}{c}{14} & 21 & 28 \\
\hline & \multicolumn{5}{c}{ Pemberian Pupuk Kandang Kambing } \\
\hline P0 (Tanpa Pupuk) & $2.00 \mathrm{a}$ & $3.60 \mathrm{a}$ & $11.00 \mathrm{a}$ & $15.40 \mathrm{a}$ \\
P1 (10 ton/ha) & $2.00 \mathrm{a}$ & $4.40 \mathrm{bc}$ & $11.60 \mathrm{ab}$ & $17.20 \mathrm{~b}$ \\
P2 (20 ton/ha) & $2.00 \mathrm{a}$ & $4.80 \mathrm{c}$ & $11.80 \mathrm{ab}$ & $18.60 \mathrm{c}$ \\
P3 (30 ton/ha) & $2.40 \mathrm{a}$ & $6.60 \mathrm{c}$ & $12.20 \mathrm{c}$ & $20.40 \mathrm{~d}$ \\
P4 (40 ton/ha) & $3.40 \mathrm{~b}$ & $7.00 \mathrm{~d}$ & $13.40 \mathrm{c}$ & $22.00 \mathrm{e}$ \\
\hline \multicolumn{1}{c}{ BNT 5\% } & 0.64 & 1.21 & 1.42 & 1.25 \\
\hline
\end{tabular}

Keterangan : Angka - angka yang diikuti dengan huruf yang sama pada baris dan kolom yangtidak berbeda nyata pada uji DMRT taraf 5\%.

Pada tabel 4 ditunjukkan bahwa pada umur pengamatan 7 HST rata-rata jumlah daun tertinggi ditunjukkan pada perlakuan P4 (Pukan Kambing 40 ton/ha) yaitu 3.40 berbeda nyata dengan semua perlakuan yang lain. Hasil terendah ditunjukkan oleh perlakuan P0 (Kontrol) yaitu 2.00 yang tidak berbeda nyata dengan P1 (Pukan Kambing 10 ton/ha) yaitu 2.00, P2 (Pukan Kambing 20 ton/ha) yaitu 2.00 dan P3 (Pukan Kambing 30 ton/ha) yaitu 2.40 jika dosis ditingkatkan 40 ton/ha mampu meningkatkan hasil 3.40 pada umur 7 HST.

Pada umur pengamatan 14 HST rata-rata jumlah daun tertinggi ditunjukkan pada perlakuan P4 (Pukan Kambing 40 ton/ha) yaitu 7.00 berbeda nyata dengan semua perlakuan yang lain. Hasil terendah ditunjukkan oleh perlakuan P0 (Kontrol) yaitu 3.60 jika dipupuk 10 ton/ha akan meningkatkan jumlah daun 4.40 dari P0 (Kontrol) yang tidak berbeda nyata dengan P2 (Pukan Kambing 20 ton/ha) yaitu 4.80 dan P3 (Pukan Kambing 30 ton/ha) yaitu 6.60 .

Pada umur pengamatan 21 HST rata-rata jumlah daun tertinggi ditunjukkan oleh perlakuan P4 (pukan kambing 40 ton/ha) yaitu 13.40 berbeda nyata dengan semua perlakuan yang lain. Hasil terendah ditunjukkan oleh perlakuan P0 (Kontrol) yaitu 11.00 yang tidak berbeda nyata dengan perlakuan P1 (Pukan Kambing 10 ton/ha) yaitu 11.60 dan P2 (Pukan Kambing 20 ton/ha) yaitu 11.80 . Jika dosis ditingkatkan 40 ton/ha mampu meningkatkan hasil 13.40 pada umur 21 HST. 
Wahyu Wardiana Dewi, 2016. Respon Dosis Pupuk Kandang Kambing Terhadap Pertumbuhan dan Hasil Tanaman Mentimun (Cucumis sativus L.)Varietas Hibrida . Journal Viabel Pertanian. (2016), 10(2) 11- 29

Pada umur pengamatan 28 HST rata-rata jumlah daun tertinggi ditunjukkan oleh perlakuan P4 (Pukan Kambing 40 ton/ha) yaitu 22.00 berbeda nyata dengan semua perlakuan yang lain. Hasil terendah ditunjukkan oleh perlakuan P0 (Kontrol) yaitu 15.40 yang berbeda nyata dengan perlakuan P1 (Pukan Kambing 10 ton/ha), P2 (Pukan Kambing 20 ton/ha) dan P3 (Pukan Kambing 30 ton/ha) jika dosis ditingkatkan 40 ton/ha mampu meningkatkan hasil 22.00 pada umur 28 HST. Grafik pengaruh perlakuan pupuk kandang kambing pada jumlah daun dapat dilihat ada gambar dibawah ini :

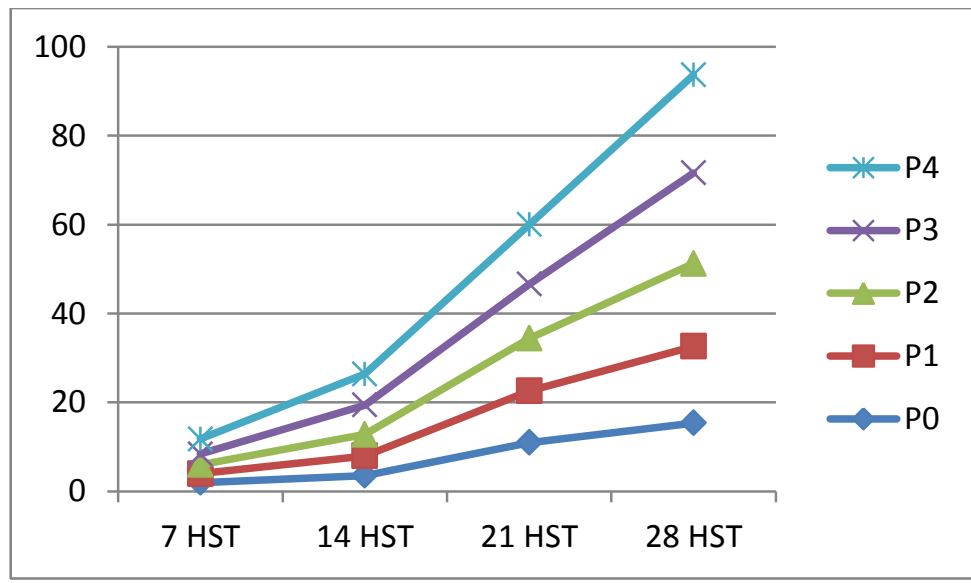

Gambar 10. Jumlah Daun Mentimun Terhadap Pemberian Pupuk Kandang Kambing Pada Semua Umur Pengamatan.

Hasil pengamatan pertumbuhan vegetatif yaitu variabel jumlah daun (Tabel 4) menunjukkan bahwa perlakuan pupuk kandang kambing dosis 40 ton/ha (P4) berbeda nyata dengan semua perlakuan yang lain. Hasil terendah ditunjukkan oleh perlakuan P0 (Kontrol) yaitu 2.00 yang tidak berbeda nyata dengan P1 (Pukan Kambing 10 ton/ha) yaitu 2.00, P2 (Pukan Kambing 20 ton/ha) yaitu 2.00 dan P3 (Pukan Kambing 30 ton/ha) yaitu 2.40. Pada perlakuan P4 (40 ton/ha) pertumbuhan vegetatif lebih cepat dan lebih tinggi yaitu sebesar 3.40 dibandingkan dengan pertumbuhan vegetatif pada perlakuan lain. Hal ini disebabkan karena kecenderungan semakin meningkatnya dosis pupuk kandang kambing yang diberikan sampai dosis 40 ton/ha mampu menyediakan jumlah kadar nitrogen yang tinggi sehingga meningkatkan jumlah daun.

\section{Panjang Buah}

Berdasarkan hasil analisis Anova taraf 5\% menunjukkan bahwa pemberian pupuk kandang kambing berpengaruh nyata terhadap panjang buah tanaman mentimun. (Lampiran 3). Rata-rata tinggi tanaman pada perlakuan pupuk kandang kambing dapat dilihat pada tabel 5 . 
Wahyu Wardiana Dewi, 2016. Respon Dosis Pupuk Kandang Kambing Terhadap

Pertumbuhan dan Hasil Tanaman Mentimun (Cucumis sativus L.)Varietas Hibrida . Journal Viabel Pertanian. (2016), 10(2) 11- 29

Tabel 5. Rata-Rata Pemberian Pupuk Kandang Kambing Terhadap Panjang Buah Tanaman Mentimun Pada Semua Umur Pengamatan.

\begin{tabular}{|c|c|}
\hline Perlakuan & Panjang Buah $(\mathrm{cm})$ \\
\hline P0 & $17.12 \mathrm{~cm} \mathrm{a}$ \\
\hline P1 & $18.60 \mathrm{~cm}$ \\
\hline P2 & $20.12 \mathrm{~cm}$ \\
\hline P3 & $22.56 \mathrm{~cm}$ \\
\hline P4 & $25.72 \mathrm{~cm}$ \\
\hline
\end{tabular}

Keterangan : Angka - angka yang diikuti dengan huruf yang sama pada baris dan kolom yang tidak berbeda nyata pada uji DMRT taraf 5\%.

Pada tabel 5 dapat dilihat rataan pemberian perlakuan pupuk kandang kambing tertinggi ditunjukkan oleh perlakuan P4 (Pukan Kambing 40 ton/ha) yaitu 25.72 berbeda nyata dengan semua perlakuan yang lain. Sedangkan rata-rata terendah ditunjukkan oleh perlakuan P0 (Kontrol) yaitu 17.12 yang berbeda nyata dengan P1 (Pukan Kambing 10 ton/ha) yaitu 18.60 , P2 (Pukan Kambing 20 ton/ha) yaitu 20.12 dan P3 (Pukan Kambing 30 ton/ha) yaitu 22.56 .Jika dipupuk 30 ton/ha akan meningkatkan panjang buah 22.56 dari P0 (Kontrol) dan jika dosis ditingkatkan 40 ton/ha mampu meningkatkan hasil 25.72

\section{Diameter Buah}

Berdasarkan hasil analisis Anova taraf 5\% menunjukkan bahwa pemberian pupuk kandang kambing berpengaruh nyata terhadap diameter buah mentimun. (Lampiran 4). Rata-rata tinggi tanaman pada perlakuan pupuk kandang kambing dapat dilihat pada tabel 6.

Tabel 6. Rata-Rata Pemberian Pupuk Kandang Kambing Terhadap Diameter Buah Tanaman Mentimun Pada Semua Umur Pengamatan.

\begin{tabular}{cc} 
Perlakuan & Diameter Buah $(\mathrm{cm})$ \\
\hline P0 & $4.36 \mathrm{~cm} \mathrm{a}$ \\
P1 & $4.62 \mathrm{~cm} \mathrm{~b}$ \\
P2 & $4.62 \mathrm{~cm} \mathrm{~b}$ \\
P3 & $5.02 \mathrm{~cm} \mathrm{c}$ \\
P4 & $6.42 \mathrm{~cm} \mathrm{~d}$ \\
\hline BNJ 5\% & 0.43
\end{tabular}

Keterangan : Angka - angka yang diikuti dengan huruf yang sama pada baris dan kolom yang tidak berbeda nyata pada uji DMRT taraf 5\%.

Pada tabel 6 dapat dilihat rataan perlakuan pemberian pupuk kandang kambing tertinggi ditunjukkan oleh perlakuan P4 (Pukan Kambing 40 ton/ha) yaitu 6.42 berbeda nyata dengan semua perlakuan yang lain. Hasil rataan terendah ditunjukkan oleh P0 
Wahyu Wardiana Dewi, 2016. Respon Dosis Pupuk Kandang Kambing Terhadap

Pertumbuhan dan Hasil Tanaman Mentimun (Cucumis sativus L.)Varietas Hibrida . Journal Viabel Pertanian. (2016), 10(2) 11- 29

(Kontrol) yaitu 4,36 berbeda nyata dengan P1 (Pukan Kambing 10 ton/ha) yaitu 4.62, P2 (Pukan Kambing 20 ton/ha) yaitu 4.62 , P3 (Pukan Kambing 30 ton/ha) yaitu 5.02 .

\section{Berat Buah}

Berdasarkan hasil analisis Anova taraf 5\% menunjukkan bahwa pemberian pupuk kandang kambing berpengaruh nyata terhadap berat buah tanaman mentimun. (Lampiran 5). Rata-rata tinggi tanaman mentimun dapat dilihat pada tabel 7.

Tabel 7. Rata-rata Pemberian Pupuk Kandang Kambing Terhadap Berat Buah Tanaman Mentimun Pada Umur 32 HST.

\begin{tabular}{|c|c|}
\hline Perlakuan & Berat Buah (gr) \\
\hline P0 & $340.33 \mathrm{gr} \quad \mathrm{a}$ \\
\hline $\mathrm{P} 1$ & $371.66 \mathrm{gr} \quad \mathrm{b}$ \\
\hline $\mathrm{P} 2$ & $424.33 \mathrm{gr}$ \\
\hline P3 & $460.32 \mathrm{gr} \quad \mathrm{d}$ \\
\hline $\mathrm{P} 4$ & $539.33 \mathrm{gr}$ e \\
\hline
\end{tabular}

Keterangan : Angka - angka yang diikuti dengan huruf yang sama pada baris dan kolom yang tidak berbeda nyata pada uji DMRT taraf 5\%.

Pada tabel 7 dapat dilihat bahwa pemberian perlakuan pupuk kandang kambing tertinggi tidak memberi pengaruh nyata pada variable berat buah. Rataan tertinggi ditunjukkan oleh perlakuan P4 (Pukan Kambing 40 ton/ha) yaitu 539.33 berbeda nyata dengan semua perlakuan yang lain. Sedangkan rata-rata terendah ditunjukkan oleh perlakuan P0 (Kontrol) yaitu 340.33 yang berbeda nyata dengan perlakuan P1 (Pukan Kambing 10 ton/ha), P2 (Pukan Kambing 20 ton/ha) dan P3 (Pukan Kambing 30 ton/ha).

\section{HASIL \& PEMBAHASAN}

\section{Respon Dosis Pupuk Kandang Kambing Terhadap Pertumbuhan Dan Hasil Tanaman Mentimun. \\ Tinggi Tanaman}

Dari hasil analisis data pada umur pengamatan 28 HST menunjukkan bahwa pemberian pupuk kandang kambing berpengaruh nyata pada tinggi tanaman. Perlakuan pemberian pupuk kandang kambing terbaik ditunjukkan pada perlakuan P4 (Pukan Kambing 40 ton/ha) sebesar 160.13 yang mampu meningkatkan $0.21 \%$ dari perlakuan P0 (Tanpa pemupukan). Penggunaan pupuk kandang kambing secara berkelanjutan memberikan dampak positif terhadap kesuburan tanah. Tanah yang subur akan mempermudah per- kembangan akar tanaman. Akar tanaman yang dapat berkembang dengan baik akan lebih mudah menyerap air dan unsur hara yang tersedia di dalam tanah sehingga tanaman dapat tumbuh dan berkembang secara optimal serta menghasilkan hasil yang tinggi.

Hal ini sesuai dengan pendapat Kusmanto et al (2010) yang menyatakan bahwa perlakuan pemberian dosis pupuk kandang kambing hingga 5 ton/ha berbeda nyata pada 
Wahyu Wardiana Dewi, 2016. Respon Dosis Pupuk Kandang Kambing Terhadap Pertumbuhan dan Hasil Tanaman Mentimun (Cucumis sativus L.)Varietas Hibrida . Journal Viabel Pertanian. (2016), 10(2) 11- 29

parameter pertumbuhan tanaman yaitu tinggi tanaman, semakin ditingkatkan dosis pupuk kandang kambing maka akan menghasilkan hasil yang optimal.

Menurut hasil penelitian Sarief (1989) mengemukakan penambahan dosis pupuk kandang kambing akan berpengaruh pada penambahan bahan organik dan bobot isi tanah. Bobot isi tanah yang rendah menjadikan kepadatan dan kekerasan tanah rendah, sehingga kondisi demikian memberikan lingkungan yang baik untuk perakaran tanaman dan secara tidak langsung memberi kemudahan penyerapan unsur hara.

Berdasarkan penelitian Sumpena dan Meilani (2005) menunjukkan pemupukan 25 ton/ha merupakan dosis yang terbaik untuk meningkatkan pertumbuhan tinggi tanaman mentimun. Hikmah (2008) kotoran kambing mengandung $1.19 \% \mathrm{~N}, 0.92 \% \mathrm{P}_{2} \mathrm{O}_{5}$, dan $1.58 \% \quad \mathrm{~K}_{2} \mathrm{O}$ sehingga semakin tinggi dosis yang diberikan maka akan semakin meningkatkan kandungan hara tanah. Dari berbagai unsur yang ada, nitrogen merupakan unsur yang sangat penting untuk pertumbuhan tanaman, unsur nitrogen bermanfaat untuk pertumbuhan vegetatif tanaman.

Hanolo (1997) menyatakan bahwa, unsur hara nitrogen pada pupuk organik memacu pertumbuhan tanaman, karena nitrogen membentuk asam-asam amino menjadi protein. Protein yang terbentuk digunakan untuk membentuk hormon pertumbuhan. Menurut Soepardi (Aria Bara et al., 2009), pupuk kandang merupakan sumber nitrogen yang memberikan pengaruh paling cepat dan menyolok pada pertumbuhan tanaman dibandingkan unsur lainnya, nitrogen yang tersedia di dalam tanah dan mencukupi kebutuhan tanaman dapat meningkatkan tinggi tanaman, sehingga mentimun dapat tumbuh dengan baik. Sebaliknya tanaman tidak dapat tumbuh dengan baik jika unsur hara nitrogen tidak tercukupi pada tanaman. Pernyataan ini diperkuat oleh Sutejo (Ari Purwanti et al, 2009), bahwa kekurangan unsur hara nitrogen menyebabkan tanaman tumbuh kerdil dan pertumbuhannya tersendat, serta daun berwarna hijau muda dan akhirnya kuning.

Hal ini sejalan dengan pendapat Subhan et al. ,2005 dan Rizwan, 2008) yang berpendapat unsur $\mathrm{N}$ yang terkandung pada pupuk kandang kambing mendorong pertumbuhan organ-organ yang berkaitan dengan fotosintesis yaitu daun. Kalium berperan sebagai aktivator berbagai enzim yang esensial dalam reaksi-reaksi fotosintesis dan respirasi serta untuk enzim yang terlibat dalam sintesis protein dan pati. Dalam tanaman, P merupakan unsur penting penyusun adenosin triphophate (ATP) yang secara langsung berperan dalam proses penyimpanan dan transfer energi yang terkait dalam proses metabolisme tanaman serta berperan dalam peningkatan komponen hasil. Hasil penelitian terdahulu oleh Suleman (2013), bahwa pemberian 20 ton/ha pupuk organik kotoran kambing pada umur 7 HST, 14 HST, 21HST, dan 28HST berpengaruh nyata terhadap pertumbuhan tanaman pada variabel tinggi tanaman mentimun, hal ini disebabkan peran pupuk organik kotoran kambing pada konsentrasi $30 \%$.

Hasil analisis data pada umur 7, 14, 21, 28 HST pemberian perlakuan pupuk kandang kambing terdapat pengaruh yang nyata pada tinggi tanaman. Unsur hara yang terkandung pada pupuk kandang kambing memberikan pengaruh paling cepat dan 
menyolok sehingga memacu pertumbuhan tanaman dikarenakan nitrogen membentuk asam-asam amino menjadi protein, protein yang terbentuk digunakan untuk membentuk hormon pertumbuhan. Hal ini yang diduga menjadi pemicu adanya pengaruh nyata pada perlakuan pemberian pupuk kandang kambing.

Pada umur 7, 14, 21, 28 HST pemberian perlakuan pupuk kandang kambing berpengaruh nyata pada tinggi tanaman, rataan tertinggi ditunjukkan oleh perlakuan P4 (40 ton/ha) hal ini di duga sumber $\mathrm{N}$ yaitu $0.7 \%$ pada pupuk kandang kambing diserap secara maksimal oleh tanaman mentimun, disebutkan bahwa fungsi $\mathrm{N}$ sebesar $0.7 \%$ yang tinggi terdapat pada pupuk kandang kambing mampu menyediakan unsur hara yang dibutuhkan oleh tanaman sehingga memungkinkan terjadinya pertambahan tinggi tanaman.

Hal ini sesuai pendapat (Campbell dkk, 2003; Salisbury dan Ross, 1995), mengatakan bahwa tanah yang porous akibat penambahan bahan organik mendukung perkembangan akar menembus masuk ke dalam tanah dan akar menyerap hara semakin banyak sehingga dapat mendukung pertumbuhan tinggi tanaman. Peningkatan nilai KTK pada pemberian dosis kotoran kambing mengakibatkan tanah mampu menjerap dan menyediakan unsur hara, akibat bobot isi tanah yang rendah berarti tanah memiliki porositas yang baik. Dengan kondisi tanah yang porous maka aerasi di dalam tanah menjadi baik, akar mempertukarkan gas dengan ruang udara tanah dengan memasukkan $\mathrm{O}_{2}$ dan membebaskan $\mathrm{CO}_{2}$. Pertukaran gas mendukung respirasi seluler sel-sel akar sehingga air dan mineral dapat terangkut dari akar menuju sistem tunas.

Pemberian perlakuan pupuk kandang kambing terdapat pengaruh yang nyata pada umur pengamatan 7, 14. 21. 28 HST. Rataan tertinggi ditunjukkan pada perlakuan P4 (Pupuk Kandang Kambing 40 ton/ha) hal ini diduga pemberian dosis pukan kambing sebanyak 40 ton/ha cukup untuk menyediakan unsur hara $\mathrm{N}$ yang dibutuhkan tanaman dan unsur $\mathrm{N}$ tersebut dapat diserap oleh tanaman mentimun dengan maksimal, hal ini berkaitan dengan kelebihan dari pupuk kandang yang dapat menaikkan bahan serap tanah terhadap air dan membantu penyerapan hara dari pupuk kimia yang ditambahkan. Kandungan unsur hara dalam pupuk kandang tidak terlalu tinggi, tetapi mempunyai keistimewaan lain yaitu mampu mengembangkan kehidupan jasad renik (mikroorganisme) di dalam tanah karena jasad renik sangat penting bagi kesuburan tanah dan sisa-sisa tanaman yang dapat diubahnya menjadi humus, senyawa-senyawa tertentu disintesisnya menjadi bahan- bahan yang berguna bagi tanaman, disamping itu juga mampu memperbaiki sifat fisik tanah seperti permeabilitas tanah, porositas tanah, struktur tanah, daya menahan air (Mulyani Sutejo, 1995 : 108).

Hal ini sesuai dengan pernyataan (Hakim, et al, 1986), bahwa kandungan unsur hara yang ada di dalam pupuk kandang kambing bermanfaat untuk merangsang pertumbuhan tanaman. Pemberian pupuk kandang kambing dapat meningkatkan kemampuan tanah menahan air, merangsang granulasi, memantapkan agregat tanah, menurunkan plastisitas dan kohesi tanah. Pemberian pupuk kandang kambing juga mampu meningkatkan KTK tanah, mengikat unsur N, P, S dalam bentuk organik sehingga terhindar dari pencucian, melarutkan sejmlah unsur, meningkatkan jumlah dan aktivitas mikroorganisme tanah.

Lebih lanjut Pratiwi et al (2007), makanan adalah sumber energi dan sumber materi untuk menyintesiskan berbagai komponen sel, jika suatu tumbuhan kekurangan sebagian 
nutrisi maka tumbuhan itu disebut mengalami defisiensi. Defisiensi mengakibatkan pertumbuhan terganggu dan jika berkelanjutan akan menyebabkan kematian. Misalnya, kekurangan nitrogen yang merupakan unsur pembentuk klorofil akan mengakibatkan daun menguning atau klorosis. Suhu pada umumnya, tumbuhan membutuhkan suhu untuk tumbuh dan berkembang dengan baik, pertumbuhan akan mengalami keterhambatan pada suhu minimum dan maksimum. (Hakim, et al, 1986) bahwa cahaya dan kelembapan yang diperlukan untuk tumbuhan sangat mempengaruhi berlangsungnya proses pertumbuhan fotosintesis. Tanah lembab dan udara kering adalah keadaanyang tepat untuk mempercepat perkembangan, akan tetapi untuk tempat yang teduh tanaman akan mengalami pertumbuhan abnormal.

\section{Jumlah Daun}

Dari hasil analisis data menunjukkan bahwa perlakuan pemberian pupuk kandang kambing terdapat pengaruh yang nyata pada variabel jumlah daun disemua umur pengamatan. Pemberian pupuk kandang kambing 40 ton/ha (P4) merupakan dosis perlakuan dengan rataan tertinggi yaitu sebesar 22.00 yang mampu meningkatkan $0.06 \%$ dari perlakuan P0 (Kontrol). Hal ini diduga, pada perlakuan P4 (pupuk kandang kambing 40 ton/ha) merupakan dosis yang mampu diserap dengan baik oleh perakaran tanaman sehingga akan mendukung berlangsungnya fotosintesis yang akan digunakan untuk pembentukan cadangan makanan untuk pertumbuhan tanaman mentimun.

Hal ini sesuai dengan pernyataan (Buckman dan Brady, 1982; Rosmarkam dan Widya, 2002; Hardjowigeno, 2007) dari berbagai unsur hara yang ada, nitrogen merupakan unsur yang sangat penting untuk pertumbuhan tanaman. Unsur hara nitrogen bermanfaat untuk pertumbuhan vegetatif tanaman, pertumbuhan vegetatif dapat berupa bertambahnya jumlah daun. Hal ini dapat dipahami karena pada titik tumbuh tertumpuknya zat pengatur tumbuh sitokinin yang berasal dari reaksi fisiologis tanaman. Sitokinin terpacu pembentukannya, jika hara $\mathrm{N}$ yang berasal dari hasil dekomposisi bahan organik.

Selanjutnya menurut Krishnamoorthy (1981), bahwa unsur nitrogen yang dominan terkandung dalam pupuk kandang kambing berfungsi dalam meningkatkan pertumbuhan vegetatif tanaman terutama untuk memacu pertumbuhan daun. Diasumsikan semakin luas daun, maka semakin tinggi fotosintat yang dihasilkan, sehingga semakin tinggi pula fotosintat yang di translokasikan. Fotosintat tersebut digunakan untuk pertumbuhan dan perkembangan tanaman, antara lain pertambahan ukuran panjang, atau tinggi tanaman, pembentukan cabang dan daun baru.

Pemberian pupuk kandang kambing dosis 40 ton/ha (P4) berbeda nyata dengan tanpa perlakuan kontrol (P0). Pemberian pupuk kandang kambing 40 ton/ha (P4) mampu meningkatkan rata-rata jumlah daun sebanyak $0.22 \%$ dari perlakuan kontrol (P0). Hal ini diduga karena pemberian pupuk kandang kambing yang diberikan diawal, pada saat pengolahan lahan telah terdekomposisi atau terurai dengan baik sehingga mudah diserap oleh akar tanaman. Menurut Sarief (1998) dalam Marisi Napitupulu (2013), bahwa tanaman akan tumbuh dengan baik dan subur apabila unsur hara yang dibutuhkan tersedia dalam cukup dan seimbang dan juga pembentukan pucuk atau daun baru dengan tersedianya nutrisi bagi tanaman. 
Hardjowigeno (2003) menyatakan bahwa, Nitrogen yang terkandung pada pupuk kandang kambing mendorong pertumbuhan organ-organ yang berkaitan dengan fotosintesis yaitu daun, kalium berperan sebagai aktivator berbagai enzim yang esensial dalam reaksi-reaksi fotosintesis dan respirasi serta untuk enzim yang terlibat dalam sintesis protein dan pati sedangkan unsur hara mikro berfungsi terutama dalam pembentukan daun dan klorofil pada daun. Apabila dalam pembentukan daun terganggu mengakibatkan proses fotosintesis akan mengalami gangguan sehingga akan mengakibatkan kekurangan nitrogen yang akan berdampak pada pertumbuhan tanaman menjadi kerdil dan lambat.

\section{Respon Dosis Pupuk Kandang Kambing Terhadap Pertumbuhan Generatif Dan Hasil Tanaman Mentimun.}

\section{Panjang Buah}

Dari hasil analisis data menunjukkan bahwa terdapat pengaruh nyata pada variabel panjang buah. Rataan tertinggi ditunjukkan oleh P4 (Pupuk Kandang Kambing 40 ton/ha) dengan hasil rataan 25.72 meningkatkan hasil $0.25 \%$ dari perlakuan P0 (Kontrol). Hal ini di duga karena pemberian pupuk kandang kambing mampu menyediakan unsur hara yang cukup dan seimbang untuk kebutuhan tanaman. Pupuk kandang kambing menyediakan unsur hara yang besar khususnya unsur hara $\mathrm{N}$, unsur tersebut berperan sangat penting dalam hubungan panjang buah yang dihasilkan.

Hal ini sesuai dengan pendapat Ghani (2002), menyatakan bahwa pemupukan N mengakibatkan meningkatnya panjang tongkol dan diameter tongkol jagung. Dengan adanya nitrogen yang tersedia maupun yang diberikan dalam bentuk pupuk berpengaruh terhadap proses fotosintesis yang dapat merubah karbohidrat menjadi protein, sehingga pertumbuhan akan lebih efektif termasuk dalam penambahan panjang buah dan diameter buah.

\section{Diameter Buah}

Dari hasil analisis data menunjukkan bahwa terdapat pengaruh nyata pada variabel diameter buah. Perlakuan tertinggi ditunjukkan oleh P4 (Pupuk Kandang Kambing 40 ton/ha) dengan hasil 6.42 yang mampu meningkatkan 0.02\% dari perlakuan P0 (Kontrol). Hal ini di duga pupuk kandang kambing mampu mengikat unsur hara dan menyediakan unsur hara sesuai kebutuhannya, sehingga dengan adanya pupuk kandang kambing efektifitas dan efisiensi pemupukan menjadi lebih tinggi. Maka unsur hara yang telah diserap tanaman dapat dimaksimalkan untuk merangsang metabolisme tanaman, sebab perkembangan jaringan tanaman sangat ditentukan oleh ketersedianan unsur hara terutama unsur $\mathrm{N}$ yang dimiliki oleh keduanya. Hal ini sesuai dengan pendapat Soegiman (1982) bahwa ketersediaan nitrogen yang cukup pada tanaman akan meningkatkan kuantitas dan kualitas hasil tanaman, ketersediaan nitrogen memegang peranan penting dalam produksi tanaman sehingga berpengaruh pada kuantitas dan kualitas suatu tanaman. Hal ini berhubungan dengan tinggi tanaman, panjang tongkol, diameter tongkol dan berat tongkol pada tanaman mentimun. 


\section{Berat Buah}

Dari hasil analisis data menunjukkan bahwa terdapat pengaruh nyata pada variabel berat buah. Perlakuan tertinggi ditunjukkan oleh P4 (Pupuk Kandang Kambing 40 ton/ha) yaitu 539.33 yang mampu meningkatkan $1.99 \%$ dari perlakuan P0 (Kontrol). Hal ini di duga karena pemberian pupuk kandang kambing mampu menyediakan unsur hara yang cukup dan seimbang untuk kebutuhan tanaman. Pupuk kandang kambing menyediakan unsur hara yang besar khususnya unsur hara $\mathrm{N}$, unsur tersebut berperan sangat penting untuk pembentukan buah.

Hal ini sesuai dengan pendapat Gardner et al., (1991) mengemukakan bahwa permukaan luas daun yang luas dan datar memungkinkan tanaman untuk menangkap cahaya semaksimal mungkin per satuan volume, laju fotosintesis tanaman ditentukan oleh besarnya luas daun dari tanaman tersebut. Semakin besar luas daun maka cahaya matahari yang terserap semakin optimal, yang nantinya digunakan untuk meningkatkan laju fotosintesis. Menurut Rosmarkam dan Yuwono (2002), pemupukan nitrogen akan menaikkan produksi tanaman, kadar protein dan kadar selulosa. Hasil asimilasi $\mathrm{CO}_{2}$ diubah menjadi karbohidrat dan disimpan dalam jaringan tanaman. Bahwa semakin besar fotosintat yang ditranslokasikan ke buah maka semakin meningkat pula berat segar buah. Berdasarkan hasil penelitian sebelumnya oleh Bara dan Chozin (2009), meyatakan bahwa berat buah mentimun pada berbagai perlakuan semakin meningkat dengan meningkatnya dosis pupuk kandang kambing dari 10 ton/ha menjadi 15 ton/ha. Selain itu, unsur P tidak kalah penting pada pertumbuhan generatif tanaman yaitu unsur $\mathrm{P}$ sebagai pembentukan buah hal ini sesuai dengan laporan Mitra et al. (1990) yang menyatakan bahwa pemberian fosfat pada tanaman mentimun dapat meningkatkan hasil buah. Penampakan fisik buah yang besar terjadi karena cadangan makanan yang ditimbun pada buah semakin banyak.

Primanto (1998) menyatakan bahwa pada masa generatif tanaman membutuhkan unsur hara yang banyak untuk menghasilkan energi bagi tanaman, yaitu fosfor dan kalium. Energi yang dibutuhkan tanaman dipakai untuk membentuk bunga serta proses pertumbuhan lainnya. Hal ini sejalan dengan pendapat Syarief (1985) menyatakan bahwa fosfor dan kalium adalah unsur penting yang banyak berperan dalam pembungaan dan pemasakan buah dan biji. Pembentukan bunga pada tanaman ini dipengaruhi oleh ketersediaan hara di dalam tanah yang berasal dari pupuk kandang kambing.

\section{KESIMPULAN DAN SARAN}

\section{KESIMPULAN}

1. Hasil analisis ragam menunjukkan bahwa pupuk kandang kambing $(\mathrm{P})$ berpengaruh nyata pada masing-masing variabel mulai dari tinggi tanaman, jumlah daun, berat buah, panjang buah dan diameter buah.

2. Perlakuan dosis pukan $(\mathrm{P})$ berpengaruh nyata terhadap semua parameter pengamatan mulai tinggi tanaman, jumlah daun, berat buah buah, panjang buah dan diameter buah. Perlakuan dosis pukan P4 (pupuk kandang kambing dosis 40 ton/ha) merupakan konsentrasi yang terbaik dengan menghasilkan nilai rata-rata tertinggi pada semua parameter. Nilai terendah pada semua parameter di tunjukkan dari P0 (tanpa pupuk/kontrol). 
Wahyu Wardiana Dewi, 2016. Respon Dosis Pupuk Kandang Kambing Terhadap

Pertumbuhan dan Hasil Tanaman Mentimun (Cucumis sativus L.)Varietas Hibrida . Journal Viabel Pertanian. (2016), 10(2) 11- 29

\section{SARAN}

1. Pada saat membudidayakan tanaman mentimun sebaiknya mengaplikasikan pupuk kandang kambing dengan takaran yang sesuai, karena dapat mempengaruhi hasil produksi.

2. Perlu adanya rekomendasi pupuk organik kotoran kambing yang tepat sesuai dengan kesuburan tanah yang dapat dijadikan dasar oleh petani dalam membudidayakan tanaman mentimun (Cucumis sativus L.).

3. Perlu dilakukan penelitian lebih lanjut tentang pemanfaatan jenis pupuk kandang kambing dengan rentang dosis yang lebih lebar pada tanaman mentimun (Cucumis sativus L.).

\section{DAFTAR PUSTAKA}

Anonim. 2007. Evaluation of The Effectivenes og Goat Dung Manureandd Kola Pod Husk Ash on Nutrient Co potition and Growth Performance. Balai Penelitian Teknolgi Pertanian Bali dan Nusa Tenggara Barat. .Hal 1-3.

Anonim. 2007. Nutrition for food.

http://www.weightlossforgood.co.uk

Ashari, S. 1995. Hortikultura Aspek Budidaya. Universitas Indonesia. Jakarta. Hlm 255257.

Bara, C. 2009. Pengaruh Pupuk Kandang Kambing Tanaman Mentimundalam Kegiatan Pertanian Organik. Jurnal Agrotropika Vol VII(2): 6-10.

Bara A., M. A. Chozin. 2009. Pengaruh Dosis Dan Frekuensi Pupuk Kandang Terhadap Pertumbuhan Dan Produksi Di Lahan Kering. Makalah Seminar Departemen Agronomi dan Hortikultura FakultasPertanianInstitutPertanianBogor.http://repository.ipb.ac.id/bitstream/handl e/123456789/35459/aria\%20bara. pdf.[08 Oktober 2012]. Hal 36 :42

BPS, 2006. Sumatera Utara dalam Angka 2006. Badan Pusat Statistik Propinsi Sumatera Utara. Medan. Hal 4 (2) : 41-47.

Buckman, H, O. dn Brady, N. C. 1982. Ilmu Tanah. Diterjemahkan oleh; Soegiman. Bhratara Karya Aksara. Jakarta. Hal 11.

Cahyono, B. 2003. Timun. Aneka Ilmu. Semarang. Hlm 3,4,8,10, dan 27.

Campbel, A. N., Reece, B. J., Mitchel, G. L. 2003. Biologi jilid 2. Erlangga. Hal 160-165.

Deptan. 2006. Prospek dan Arah Pengembangan Budidaya Timun. Jakarta. 11 hal.

Dinariani. 2013. Sifat dan Fungsi Pupuk Kandang. http://etd.eprints.ums.ac.id/14422/2/BAB_I.pdf.

Evita. 2009. Pertumbuhan dan Hasil Tanaman Mentimun Cucumis sativus L. terhadap pemberian Pupuk Kandang Padat. Percikan 96: 65-68.

Gardner, F. P., R. B. Pearce, dan R. L. Mitchell. 1991.Fisiologi Tanaman Budidaya (terjemahan). UI. Hal 86.

Gavras, M. F. 1990. The Influence Of Mineral Nutrition, Sta ge of Harvests and Flower Position on Seed Yield and Quality of Cucumis sativus L. Field Crop Abstract 43: 4213. 
Wahyu Wardiana Dewi, 2016. Respon Dosis Pupuk Kandang Kambing Terhadap

Pertumbuhan dan Hasil Tanaman Mentimun (Cucumis sativus L.)Varietas Hibrida . Journal Viabel Pertanian. (2016), 10(2) 11 - 29

Ghani, M. A. 2002. Buku Pintar Mandor: Dasar-Dasar Budidaya Mentimun. PT. Penebar Swadaya. Jakarta. 134 hal.

Hakim N. 1986. Pengaruh Berbagai Jenis Pupuk Kandang terhadap

Pertumbuhan dan Produksi Mentimun. Jurnal Sains, Matematika dan Teknologi 2 (20) : 5-12.

Hanolo, W. 1997. Tanggapan Tanaman Mentimun (Cucumis sativus L) Terhadap Dosis dan Cara Pemberian Pupuk Cair Stimulan. Jurnal Agrotropika. Hal 10.

Hardjowigeno. 2007. Teknik dan Strategi Budidaya Mentimun (Cucumis sativus L.). Yayasan Pustaka Nusantara. Yogyakarta. Hal 59.

Hardjowigeno Sarwono 2007. Ilmu Tanah. Akademia Pressindo Jakarta. Hal 73-81.

Hikmah, A. 2008. Pemberian Beberapa Bahan Organik Pada Budidaya Tanaman Mentimun (Cucumis sativus L.) Serta Pengaruh Terhadap Pertumbuhan Dan Serapan Cu Dan Zn. Skripsi. Fakultas Pertanian. IPB. Bogor. Hal 185- 189.

Isnaini, M. 2006. Pertanian Organik. Kreasi Wacana. Yogyakarta. Hlm 247-248.

Kusmanto et al. 2010. Kesuburan dan Pemupukan Tanah Pertanian. Pustaka Buana, Bandung. Hal 317-321.

Krishnamoorthy, H.N. 1981. Plant Growth and Development. Tata Mac Grow-Hill. Publishing Company Ltd. New Delhi. 53 hal.

Lilis.2013. Kesuburan dan Pemupukan

Tanah Pertanian. Pustaka Buana, Bandung. Jilid I. 86 hal.

Matarirano. 1994. Pupuk Akar Jenis dan Aplikasi. Penebar Swadaya, Jakarta. Hlm 23-33.

Mitra, S. K., Sadhu , M. L. 1990. Evaluasi Pupuk Kandang Terhadap Pertumbuhan dan Produksi Tanaman Mentimun. Jurnal Ilmiah Abdi Ilmu 3. (2): 150-158.

Murbandono. 2000. Petunjuk Penggunaan Pupuk. Penebar Swadaya. Jakarta. Hlm 4-10.

Musnamar, E. I. 2003. Pembuatan dan

Aplikasi Pupuk Organik Padat. Penebar Swadaya. Jakarta. Hlm 1-2.

Pinus Lingga. 1991. Laporan Kuliah

Kerja Lapangan Kajian Jenis

Pupuk Organik Terhadap Pertumbuhan.Fakultas Pertanian. Institut Pertanian Bogor. Bogor. Hal 183-196.

Pratiwi. 2007. Prinsip-Prinsip Biologi Tumbuhan Untuk Daerah Tropik. Gramedia Pustaka Utama. Jakarta. 182 hal.

Primanto, H. 1998. Pemupukan Tanaman Buah. Penebar Swadaya. Jakarta. 73 hal.

Rukmana, R. 1994. Budidaya Mentimun. Kanisius. Yogyakarta. Hlm 11,12,17, dan 36.

Rosmarkam, A, dan Yuwono, W. Nasih. 2002. Ilmu Kesuburan Tanah. Kanisius. Yogyakarta. Vol VIII (2) : 6-10.

Salisbury, B. Frank dan Ross, W. C. 1995. Fisiologi Tumbuhan Jilid 2 dan 3. ITB. Bandung. Hal 88.

Sarief, S. 1989. Kesuburan dan Pemupukan Tanah Pertanian. Pustaka Buana, Bandung. Hlm 120-125.

Sarief, S. 1989. Fisika-Kimia Tanah Pertanian. Pusaka Buana. Bandung. Hlm 125-132. 
Wahyu Wardiana Dewi, 2016. Respon Dosis Pupuk Kandang Kambing Terhadap

Pertumbuhan dan Hasil Tanaman Mentimun (Cucumis sativus L.)Varietas Hibrida . Journal Viabel Pertanian. (2016), 10(2) 11- 29

Sharma, O. P. 2002. Plant Taxonomy, Tata McGraw, Hill Publishing Company Limited. New Delhi. Hlm 297-301.

Subhan et al.,2005 dan Rizwan, 2008.Pengaruh Pupuk Kandang Terhadap Produksi Mentimun (Cucumis sativus L.). Hlm 15-24.

Sumpena , U. 2001. Budi Daya Mentimun. Penebar Swadaya. Jakarta. Hlm1 dan 19

.Sumpena, U. dan Meilani, I. 2005. Pengaruh Pupuk Organik Terhadap Pertumbuhan dan Hasil Mentimun (Cucumis sativusL.). J. Agrivigor Vol. 5,No.1, hal 26-33

Sutejo, M dan Kartasapoetra. 1990. Pupuk dan Cara Pemupukan. PT.Rine Cipta, Jakarta. Hlm 3-37.

Sutanto, R. 2002. Pertanian Organik. Kanisius. Yogyakarta. Hlm 15,27 dan 200.

Soegiman. (1982). Pengaruh Pemberian Bahan Organik terhadap Perkembangan Tanaman Mentimun (Cucumis sativus L.). Hlm 264-267.

Soepardi. Dan Aria Bara. 2009. Pupuk Organik Dan Pupuk Hayati. Balai Besar Litbang Sumberdaya Lahan Pertanian Badan Penelitian Dan Pengembangan Pertanian. Bogor. 235 hal.

Trias Budi Rahayu. 2014. Pengaruh Dosis dan Frekuensi Pemberian Pupuk Kandang Terhadap Pertumbuhan dan Hasil. Skripsi UKSW. Salatiga. Hlm 77-96.

Warintek. 2006. Mentimun. Available at: http://Warintek. Progessio, or.id/ (06 Agustus 2006). Hlm 20-31.

Whitaker dan Bemis. 1976. Bertanam Mentimun. Kanisius. Yogyakarta. Hal 211- 216.

Wiyanta. 2005. Agronomi . PT Raja Grafindo Persada. Jakarta. Hlm 321-328. 